passed giving legal status to marriages of Asiatics according to their several religious tenets, while thousands of native Christians, who are demanding legal status for their marriages, are denied this right.

The section on Africa in the Tambaram Report gives an excellent exposition of the meaning of Christian marriage, and of its incalculable value for the development of the spiritual life of the Church. At a time such as this when the Christian Church, with all the centuries of history and tradition behind it, is gravely concerned for the preservation of the sanctity of the marriage bond, it behoves us to support the Native Churches, younger in their experience, in their desire to reach the true spiritual strength and beauty of life under the inspiration of real Christian marriage.

(Communicated by William Y. Turner.)

\title{
Congo Swahili
}

A CONFERENCE of representatives of missions from the eastern half of Congo, together with the local secretary of the Bible Society, was held on 30-3 I October 1946. The purpose of the conference was to consider the production of a common form of Swahili for use as a literary medium-and especially for translations of the Bible--throughout the area from Élisabethville to Aba. The conference was able to devise an agreed form, to be known as Congo Swahili, and to make plans for the translation of the New Testament. It passed a number of resolutions defining the orthographical and grammatical principles to be followed, enjoining their adoption by Swahili-speaking missions in the area, and providing for the revision of existing manuscripts and publications.

\section{Conférence Coloniale Franco-Belge}

UNE conférence coloniale franco-belge s'est ouvert le 27 janvier à Bruxelles. Elle devait examiner les méthodes d'administration dans les colonies françaises et au Congo Belge et établir les bases d'un échange permanent d'information entre les administrations métropolitaines et coloniales des deux pays.

\section{Portugal: Training for the Colonial Service}

ThE 'Escola Superior Colonial' was founded in 1906 for the purpose of giving 'the instruction most generally considered as indispensable to Colonial Administrators '. The college has aimed at becoming the centre of training for colonial officers and the only institution where a general knowledge of colonial cultural questions can be acquired, though persons not destined for the colonial service have also been admitted as students. Recently reforms have been instituted, under which two entirely different courses will be included in the school's curriculum; one, practical and professional, for colonial officers and administrators, and another in which the knowledge of experts who have made specialized scientific studies of colonial questions will be systematized and made available to students. The second course will embrace such subjects as international colonial law, colonial history and administration, native institutions and economies, native literature, languages, and art.

\section{Cost of Living in Nigeria. ${ }^{\mathrm{I}}$}

THE Commission appointed to inquire into the cost of living in Nigeria published its report in October 1946. The report describes the method of conducting the inquiry; during the first stage, sessions were held at Lagos where statements were read by trades union and government representatives; later the Commissioner (Mr. Tudor Davies) and Mr. Dalley, the assessor, made a tour of the territory in order to acquaint themselves with local condi-

"Inguiry into the Cost of Living and the Control of the Cost of Living in the Colony and Protectorate of Nigeria, Col. No. 204, H.M.S.O., I946, 3s. 6 d. 